\title{
Late Effects and Survivorship Issues in Patients with Neuroblastoma
}

\author{
Danielle Novetsky Friedman 1,2,*(i) and Tara O. Henderson ${ }^{3}$ \\ 1 Department of Pediatrics, Memorial Sloan Kettering Cancer Center, 1275 York Avenue, New York, \\ NY 10065, USA \\ 2 Department of Pediatrics, Weill Cornell Medical College, New York, NY 10065, USA \\ 3 Department of Pediatrics, Comer Children's Hospital, University of Chicago, Chicago, IL 60637, USA; \\ thenderson@peds.bsd.uchicago.edu \\ * Correspondence: friedmad@mskcc.org; Tel.: +1-212-639-7376
}

Received: 29 June 2018; Accepted: 1 August 2018; Published: 6 August 2018

\begin{abstract}
Over the past two decades, marked progress has been made in understanding the biology of neuroblastoma; this has led to refined risk stratification and treatment modifications with resultant increasing 5-year survival rates for children with neuroblastoma. Survivors, however, remain at risk for a wide variety of potential treatment-related complications, or "late effects", which may lead to excess morbidity and premature mortality in this cohort. This review summarizes the existing survivorship literature on long-term health outcomes for survivors of neuroblastoma, focusing specifically on potential injury to the endocrine, sensory, cardiovascular, pulmonary, and renal systems, as well as survivors' treatment-related risk for subsequent neoplasms and impaired quality of life. Additional work is needed to assess the potential late effects of newer multimodality therapies with the aim of optimizing long-term medical and psychosocial outcomes for all survivors of neuroblastoma.
\end{abstract}

Keywords: neuroblastoma; late effects; childhood cancer; survivorship

\section{Introduction}

Neuroblastoma is the most common extracranial solid tumor of childhood, with approximately 800 cases diagnosed per year in the United States, typically in children under the age of five [1]. The disease is marked by its clinical heterogeneity, with five-year survival rates ranging from $95 \%$ for those with low-risk disease to $50 \%$ for those with high risk disease [2]. With recognition of this discrepancy, therapeutic efforts over the past several decades have focused on de-escalating therapy for those with low or intermediate risk disease, and intensifying therapy for those with high-risk disease [3-11]. Thus, contemporary treatment for low-risk disease is often restricted to surgery alone with limited use of chemotherapy [12], while patients with intermediate risk disease receive multiple cycles of chemotherapy with surgery (and radiation, if needed), and those with high-risk disease receive multimodality therapy including high-dose chemotherapy, radiotherapy, stem cell transplantation, and novel biologic and immunotherapeutic approaches, including cis-retinoic acid [9,13-17].

Given the wide variation in stage-based treatment protocols, survivors of neuroblastoma are at risk for a broad variety of treatment-related morbidities, or "late effects". These complications are directly related to the types of therapies administered as well as demographic factors such as age at treatment, sex, and genetic background [18-23]. Given the complexity of these patients, continued lifelong care in a dedicated long-term follow-up program is ideal. However, this review provides an overview of the most common late effects and survivorship issues for individuals with a history of neuroblastoma and is intended for the pediatrician who may be providing continued care to survivors 
of neuroblastoma. Systematic monitoring of these potential late toxicities allows for early detection, treatment, and prevention of long-term morbidity in this population, with the aim of improving the long-term quantity and quality of life of survivors.

\section{Late Effects in Survivors of Childhood Cancer: An Overview}

The largest reports of long-term morbidity and mortality in neuroblastoma survivors have emerged from the North American Childhood Cancer Survivor Study (CCSS), a multi-institutional retrospective cohort study that provides longitudinal follow-up on 5-year survivors of a range of childhood cancers diagnosed before the age 21 years [24,25]. In a landmark study of 10,937 childhood cancer survivors, which included individuals diagnosed with neuroblastoma, leukemia, central nervous system tumors, Hodgkin's lymphoma, non-Hodgkin's lymphoma, Wilms' tumor, soft-tissue sarcoma, and bone tumors between 1970 and 1986, the cumulative incidence of any chronic health condition at 30 years after primary cancer diagnosis was $73.4 \%$, with an estimated incidence of $42.4 \%$ for a severe, disabling, life-threatening, or fatal condition [26]. While neuroblastoma-specific risk or stage data were not included in this analysis, it is likely, given the dates of diagnosis, that the majority of included neuroblastoma survivors had low- or intermediate-risk disease.

Since that initial report, treatment has intensified for high-risk neuroblastoma patients, with resultant increases in therapy-related toxicity. It is thus not surprising that in a recent analysis on changing trends in late mortality among CCSS childhood cancer survivors diagnosed from 1970-1999, neuroblastoma survivors were one of the only diagnostic sub-groups found to have an increase in late mortality among those treated in more recent decades [27]. We hypothesize that the cohort of patients treated in the 1990s includes a higher proportion of high-risk patients, relative to survivors diagnosed in the 1970s and 1980s, which is associated with both improved survival and an increased burden of late toxicities (due to treatment with novel combinations of intensive multimodality therapy).

\section{Long-Term Medical Outcomes in Survivors of Neuroblastoma}

Several analyses have focused specifically on the delineation of late effects in neuroblastoma survivors. One analysis of 954 5-year CCSS neuroblastoma survivors, diagnosed between 1970 and 1986, found that survivors of neuroblastoma had an increased rate of mortality and second malignancies, when compared to age- and sex-matched US population controls, and an 8-fold increased risk of chronic health conditions, when compared to 3899 CCSS siblings [22]. The most prevalent chronic medical conditions involved the neurological, sensory, endocrine, and musculoskeletal systems. Survivors treated with multimodality therapy were 2.2-fold more likely to develop a chronic health condition, when compared to survivors treated with surgery alone. It is likely that most of these patients had low- or intermediate-risk disease, which was potentially over-treated.

With the introduction of risk stratification and intensification of therapy for those with high-risk disease, recent analyses have focused on long-term toxicities among this subset of survivors $[18,20,21,28,29]$. One single-institution study of 63 advanced stage neuroblastoma survivors, the majority of whom were treated with multimodality therapy between 1970 and 2001, detected late complications in $95 \%$ of survivors, including hearing loss $(62 \%)$, primary hypothyroidism $(24 \%)$, ovarian failure (41\% of females), musculoskeletal abnormalities $(19 \%)$, and pulmonary abnormalities (19\%) [21]. Other reports have similarly observed a high prevalence of late effects in this cohort, the majority of which are related to the endocrine system, ototoxicity, or subsequent malignancies [20,21,23,30-32].

While many of these complications are mild-moderate in severity, a recent report of long-term risk of hospitalization in survivors of childhood cancer in Denmark, Finland, Iceland, and Sweden found that survivors of neuroblastoma were at highest risk among all diagnostic groups for subsequent hospitalization [33]. Risk for diseases requiring inpatient treatment occurred many decades after cancer therapy, thus underscoring the need for continued risk-based screening and long-term follow-up for 
both mild-moderate and severe complications among survivors of neuroblastoma. Table 1 outlines select neuroblastoma-directed therapies and their potential late effects.

Table 1. Potential late effects after select neuroblastoma-directed therapies.

\begin{tabular}{|c|c|}
\hline Potential Late Effect & Therapeutic Exposure \\
\hline Thyroid dysfunction & $\begin{array}{c}\text { Radiation to the neck or scatter } \\
\text { Total body irradiation } \\
\text { Iodine-131 Meta-iodobenzylguanidine (I-131 MIBG) therapy } \\
\text { High-dose alkylating agents prior to transplant }\end{array}$ \\
\hline Growth hormone deficiency & $\begin{array}{l}\text { Radiation to the hypothalamic-pituitary axis ( } \geq 18 \mathrm{~Gy} \text { ) } \\
\text { Total body irradiation }\end{array}$ \\
\hline Gonadal dysfunction & $\begin{array}{l}\text { Alkylating agents } \\
\text { Cisplatin } \\
\text { Radiation to the gonads }\end{array}$ \\
\hline Skeletal dysplasia & $\begin{array}{c}\text { Radiation to the spine or long bones } \\
\text { Cis-retinoic-acid }\end{array}$ \\
\hline Diabetes Mellitus & $\begin{array}{l}\text { Abdominal radiation } \\
\text { Total body irradiation }\end{array}$ \\
\hline Hearing loss & $\begin{array}{l}\text { Cisplatin } \\
\text { Myeloablative doses of carboplatin } \\
\text { Ototoxic antibiotic exposures }\end{array}$ \\
\hline Pulmonary dysfunction & $\begin{array}{l}\text { Busulfan } \\
\text { Radiation to the chest or upper abdomen }\end{array}$ \\
\hline Cardiac dysfunction & $\begin{array}{l}\text { Anthracyclines } \\
\text { Radiation to the chest or upper abdomen }\end{array}$ \\
\hline Renal dysfunction & $\begin{array}{c}\text { Nephrectomy } \\
\text { Platinum-based chemotherapy (cisplatin, carboplatin) } \\
\text { Radiation therapy involving the kidney }\end{array}$ \\
\hline Subsequent malignancies & $\begin{array}{l}\text { Epipodophyllotoxins } \\
\text { Alkylating agents } \\
\text { Anthracyclines } \\
\text { Radiation therapy }\end{array}$ \\
\hline
\end{tabular}

\subsection{Endocrinopathies}

Endocrinopathies are one of the most prevalent complications after treatment of childhood cancer $[34,35]$ and are especially common among high-risk neuroblastoma survivors treated with multimodality therapy [20,21,36,37]. In one report of 25 long-term high-risk neuroblastoma survivors treated with high-dose chemotherapy with autologous stem cell transplant without the use of total body irradiation (TBI), the majority of patients had endocrine-related late effects, including primary hypothyroidism, growth failure, and hypogonadism [18].

\subsubsection{Thyroid Dysfunction}

Survivors exposed to radiation to the neck, such as TBI, and/or high-dose alkylating agents, particularly when administered prior to transplant, are at risk for developing primary hypothyroidism [35,38]. High rates of irreversible thyroid dysfunction have been reported after iodine-131 metaiodobenzylguanidine (I-131 MIBG) therapy [39-41]. Survivors with these risk factors should have annual monitoring of thyroid stimulating hormone (TSH) levels, with serum free T4 levels added in those with elevated TSH levels. Treatment with levothyroxine is indicated for any survivor diagnosed with primary hypothyroidism. 


\subsubsection{Linear Growth and Bone Health}

Poor linear growth is common among neuroblastoma survivors, particularly among those exposed to conditioning regimens containing TBI [42-44]. One study of 51 high-risk neuroblastoma survivors ( $n=41$ exposed to TBI) found that height was significantly impacted, with a change in Z-score of -1.91 for those exposed to TBI and -0.77 for those not exposed to TBI [20]. Survivors exposed to TBI or cranial radiation (with hypothalamic-pituitary doses $\geq 18 \mathrm{~Gy}$ ) may be at risk for growth hormone deficiency and central precocious puberty [45]. As mentioned above, neuroblastoma survivors are also at high risk for thyroid dysfunction [20,41], which can negatively impact linear growth if not adequately treated [36].

In addition to these endocrine etiologies of poor growth, neuroblastoma survivors' final height may be negatively impacted by non-endocrine causes as well, such as radiation-induced direct damage to the growth plates of the spine or long bones [46]. Single-institution reports have also indicated that those exposed to 13-cis-retinoic acid may be at risk for advanced bone age and premature epiphyseal fusion [47], which may further affect survivors' final height [47].

Radiation to bone, which is known to have a direct cytotoxic effect on epiphyseal chondrocytes, can also lead to localized osteopenia and kyphoscoliosis [48]. Individuals with therapy-related growth hormone deficiency or hypogonadism are also at risk for bone mineral density deficits [48]. Survivors with low bone mineral density should be counseled about dietary changes and supplementation, when indicated, to ensure adequate calcium and vitamin D intake.

All survivors with suboptimal linear growth should be referred to an endocrinologist for consideration of growth hormone stimulation testing. Those with kyphoscoliosis identified on physical exam should be referred to an orthopedist for consideration of further management.

\subsubsection{Hypogonadism and Impaired Fertility}

Childhood cancer survivors treated with intensive multimodality therapy, including those with a history of neuroblastoma, are at risk for gonadal dysfunction. Females treated with high-dose alkylating agents prior to autologous stem cell transplant and/or TBI may experience premature ovarian insufficiency and/or future infertility [49-51]; primary ovarian insufficiency has also been reported in females treated with I-131 MIBG therapy [52]. Given their young age at treatment, female neuroblastoma survivors treated with intensive multimodality therapy may experience absent, arrested, or delayed puberty and require referral to a pediatric endocrinologist for appropriate management [53]. Males treated with high-doses of alkylating agents and/or TBI are at risk for future infertility as well [54-56].

At entry to survivorship, risk for future infertility and alternative family building options should be discussed with all survivors in a developmentally appropriate way that respects the patient's personal values. For female survivors who experience menarche spontaneously with normal gonadotropins, post-treatment fertility preservation via oocyte or embryo freezing is available. Those interested should be referred to a reproductive endocrinologist for further discussion, evaluation, and management.

\subsubsection{Diabetes and Metabolic Syndrome}

Neuroblastoma survivors treated with abdominal radiation are at increased for components of the metabolic syndrome $[57,58]$ and diabetes mellitus $[59,60]$. When compared to siblings, survivors of neuroblastoma exposed to abdominal radiation had a 6.9-fold increased risk for diabetes; neuroblastoma survivors without a history of abdominal radiation were not at increased risk [59]. Individuals treated with TBI are at even higher risk for these complications [20,59,61-63]. Further complicating this risk for metabolic dysfunction, male neuroblastoma survivors have been found to be less physically active than their peers [64]. It is thus imperative for survivors of neuroblastoma exposed to abdominal radiation or TBI to be counseled regularly about the importance of dietary modification and regular physical activity as a preventive measure. At-risk survivors should 
be monitored with a fasting blood glucose or hemoglobin A1c every two years. Those with elevated blood glucose levels should be referred to a pediatric endocrinologist for further management.

\subsection{Ototoxicity}

Given the wide use of platinum-based chemotherapy for the treatment of neuroblastoma, profound hearing loss is a pervasive problem, particularly among those with a history of high-risk disease [29,65-71]. The prevalence of ototoxicity in this cohort ranges from $13 \%$ to $95 \%$ in published reports; exposure to cisplatin in combination with myeloablative doses of carboplatin significantly increases risk [32]. Exposure to ototoxic antibiotics during therapy likely compounds this risk. Neuroblastoma survivors with hearing loss have been found to be at increased risk for learning problems and psychosocial impairments [72]. In order to optimize educational and psychosocial outcomes in this cohort, it is essential for neuroblastoma survivors to be screened for ototoxicity and referred for hearing services and hearing aids, if indicated, in a timely manner. A recent report has also indicated that neuroblastoma survivors with profound hearing loss may be good candidates for cochlear implantation [73], which may be a therapeutic option for some affected survivors. Furthermore, early phase studies of instillation of agents into the middle ear to reduce platinum-related ototoxicity are underway.

\subsection{Pulmonary Dysfunction}

Adverse pulmonary outcomes have been reported as a late effect of neuroblastoma therapy [74], particularly among those with high-risk disease $[21,75,76]$, and are thought to be multifactorial in nature. One study of 39 high-risk neuroblastoma survivors who underwent pulmonary function testing (PFT) found that 33\% reported chronic respiratory symptoms; however, PFT abnormalities were mostly mild to moderate in severity [77]. Another case series reported on six survivors of high-risk neuroblastoma who developed bronchiectasis; all six patients were treated with multimodality therapy including busulfan/melphalan prior to autologous transplant [78], which is known to induce pulmonary toxicity.

Individuals exposed to known therapies with potential pulmonary toxicity (radiation to the lungs, pulmonary-toxic chemotherapies) should have a baseline PFT at entry to long-term follow-up, with testing repeated as clinically indicated. Patient should be counseled about smoking avoidance as well.

\subsection{Cardiac Dysfunction}

Cardiovascular disease contributes to early morbidity and mortality among all childhood cancer survivors treated with cardiotoxic therapy, such as anthracyclines and/or chest-directed radiation, and may include cardiomyopathy/heart failure, coronary artery disease, stroke, pericardial disease, arrhythmias, and valvular dysfunction $[79,80]$. Given that doxorubicin is an integral component of many protocols for the treatment of neuroblastoma patients in North America (albeit with lower cumulative doses than other childhood cancer survivor cohorts), survivors should receive appropriate risk-based screening with serial echocardiograms [81] and report any new cardiac symptoms to their treating physician. With regards to neuroblastoma specifically, one study showed that survivors of neuroblastoma had a 4.1-fold increased risk of congestive heart failure, 11.1-fold increased risk of myocardial infarction; 5.1-fold increased risk of pericardial disease; and 7.7-fold increased risk of valvular abnormalities, when compared to unaffected siblings [82], thus highlighting the need for careful cardiac follow-up in this cohort and the need for vigilant reporting of symptoms to a medical provider. All survivors should be screened with echocardiograms at intervals tailored to their cumulative dose of anthracyclines and/or history of chest-directed radiation exposure [81]. 


\subsection{Renal Dysfunction}

The data on renal dysfunction among neuroblastoma survivors are conflicting. A recent Cochrane review of early and late renal dysfunction in childhood cancer survivors treated with nephrotoxic therapies, including cisplatin, carboplatin, ifosfamide, radiation therapy involving the kidney region, and/or nephrectomy, found that the prevalence of renal adverse effects ranged from $0 \%$ to $84 \%$ across studies [83]. Definitive conclusions could not be drawn regarding the prevalence of renal dysfunction, or its risk factors, after administration of these potentially nephrotoxic therapies. However, a recent single-institution analysis of 266 high-risk neuroblastoma survivors treated with abdominal radiation found that zero patients developed chronic renal insufficiency at a median follow-up of 3.5 years [84]. Given that neuroblastoma survivors often undergo nephrectomy, receive potentially nephrotoxic chemotherapy, radiation to the kidney(s), and potentially nephrotoxic antibiotics, further work is needed to clarify survivors' risk for late renal toxicity.

\subsection{Subsequent Malignant Neoplasms and Second Neoplasms}

Neuroblastoma survivors treated with contemporary intensive multimodality therapies are at increased risk for subsequent malignant neoplasms (SMNs), including treatment-related acute myelogenous leukemia (AML) $[23,30,85,86]$. A review of 5987 patients in the International Neuroblastoma Risk Group database demonstrated that the 10-year cumulative incidence of a SMN among high-risk patients was $1.8 \%$, compared with $0.38 \%$ for low-risk patients $(p=0.01)$ [30]. In this study, the standardized incidence ratio (SIR) of AML, or the ratio of the observed numbers of patients with AML compared to the expected numbers in the general population, was 106.8 and 127.7, respectively, for patients treated on high- and intermediate-risk clinical trials [30]. Others have similarly reported a high incidence of secondary AML/myelodysplastic syndrome (MDS) $[87,88]$ as well as increased risk of secondary AML/MDS with increase in the number of dose-intensive chemotherapy cycles received [89].

In addition to hematologic malignancies, neuroblastoma survivors are also at risk for a variety of subsequent solid SMNs. It is well known that prior radiation exposure is associated with the development of subsequent solid tumors in all cancer survivors [90,91], including those with a history of neuroblastoma [92]. Additionally, a specific association has been noted between neuroblastoma and secondary renal cell carcinoma (RCC) [93-97], which may be related to prior cisplatin exposure [97]. Among 954 neuroblastoma survivors in the CCSS original cohort, eight patients developed RCC with an SIR of 85.8; neuroblastoma survivors had the highest risk of secondary RCC among all primary diagnostic groups $[97,98]$. Neuroblastoma survivors have also been found to have increased SIRs for subsequent head and neck carcinomas (SIR 20.9) and female genitourinary carcinomas (SIR 19.1) [98], secondary thyroid papillary carcinoma, chondrosarcoma, hepatocellular carcinoma, biliary adenocarcinoma [87], and melanoma [99]. In order to improve SMN-related morbidity and mortality in this cohort, it is imperative that survivors follow recommended SMN screening guidelines [81], including early breast cancer screening for females exposed to chest-directed radiation, colorectal cancer screening for those exposed to high-dose radiation to the abdomen, and skin cancer screening for individuals previously exposed to therapeutic radiation.

Survivors of neuroblastoma have also been shown to be at risk for benign subsequent neoplasms, including osteochondromas or osteocartilaginous exostoses, both inside and outside the radiation field [100], and hepatic focal nodular hyperplasia [101-104], which may be incidentally noted on routine surveillance imaging. Survivors and their family members should be reassured about the benign nature of these lesions when detected incidentally on routine imaging or clinical examination.

\section{Long-Term Psychosocial and Psychological Outcomes}

In addition to potential medical morbidities, neuroblastoma survivors have been shown to be at increased risk for psychological problems and impaired quality of life. A recent study of 8595 -year 
survivors of neuroblastoma diagnosed between 1970 and 1999 with attained age $<18$ years showed that survivors had an increased prevalence of impairment in the domains of anxiety/depression, headstrong behavior, attention deficits, peer conflict/social withdrawal, and antisocial behavior ( $16 \%$ vs. $12 \% ; p=0.01$, when compared to 872 siblings [105]. Psychological impairment was associated with special education service usage and educational attainment less than college [105]. Interestingly, there was no association between treatment intensity and worse psychological outcomes in this cohort. While increased risk of psychological distress has been noted when comparing neuroblastoma survivors to siblings, no differences were noted when comparing individuals with a history of neuroblastoma to other solid tumor survivors [106].

Prior analyses have similarly shown that neuroblastoma survivors score below the population mean score on the Mental Component Summary of the Short Form-36 (SF-36) (population mean $=50$; neuroblastoma mean $=42.4 ; p<0.0001$ ), thus reflecting decreased emotional health [107]. Another study showed that adult neuroblastoma survivors had lower individual and household incomes; were less likely to have ever been employed; and were less likely to have ever married, when compared to siblings, thus suggesting decreased social integration [22]. It is unclear whether more contemporarily treated neuroblastoma survivors experience similar psychosocial and health-related quality of life outcomes; further work is needed to clarify quality of life and psychosocial outcomes in this cohort.

Given their young age at treatment, however, it is reasonable to refer neuroblastoma survivors for formal neuropsychological testing at entry to long-term follow-up, in order to enable implementation of educational supports at a young age and optimize educational achievement in this cohort.

\section{Risk-Based Screening and the Importance of Survivorship Care}

Given the high prevalence of late medical and psychosocial morbidities in neuroblastoma survivors, and the unique long-term needs of this population, it is imperative that survivors of neuroblastoma receive appropriate lifelong risk-based care in a dedicated survivorship clinic. Many of the toxicities described have a prolonged, clinically silent latency period; appropriate risk-based screening can enable early detection and treatment, when possible, of potential treatment-related complications.

In the United States, survivorship clinics generally follow the evidence-based surveillance guidelines published by the Children's Oncology Group (COG), which are updated every 5 years and publicly available online at http:/ / www.survivorshipguidelines.org [81]. Additionally, the Children's Oncology Group is currently recruiting participants for the LEAHRN (Late Effects After High-Risk Neuroblastoma) Study, which will comprehensively assess late effects in 5-year survivors of high-risk neuroblastoma diagnosed on or after 1 January 2000.

Efforts are also underway to harmonize guidelines internationally between international cooperative groups, including COG, the Dutch Childhood Oncology group (DCOG), the UK Children's Cancer and Leukaemia Group (CCLG), and the Scottish Intercollegiate Guidelines Network (SIGN) [108]. Once complete, this effort will establish an integrated strategy for the surveillance of late effects in childhood and young adult cancer survivors worldwide.

At our institutions, at entry to long-term follow-pp, survivors and their families receive a summary of all cancer treatments, or survivorship care plan, received with an outline of potential late effects and COG-based screening recommendations (Figure 1). In addition to a comprehensive history and physical examination, appropriate screening tests are coordinated on the day of the visit. We also review the importance of healthy lifestyle behaviors, such as diet and exercise, as well as the dangers of cigarette smoking and secondhand smoke, and review academic performance and psychosocial health. All patients have the option of meeting with a dedicated nutritionist and/or social worker at each survivorship visit. Depending on the intensity of treatment received, and the risk for late effects, survivors are generally followed every 6 or 12 months for continued risk-based screening and management of potential complications that arise. Ideally, all survivors should be followed by 
a primary care physician in conjunction with the treating cancer center (either the primary oncologist and/or a dedicated long-term follow-up program) and follow risk-based screening as outlined on the survivorship care plan. Lifelong annual survivorship visits, which are generally covered by insurance, are recommended for early detection and management of potential late effects.

\begin{tabular}{|c|c|c|c|}
\hline \multicolumn{4}{|c|}{ SUMMARY OF CANCER TREATMENT } \\
\hline \multicolumn{2}{|l|}{ Name: John Doe } & Date of Birth: & \\
\hline \multicolumn{4}{|c|}{ Cancer Diagnosis: Neuroblastoma, stage IV } \\
\hline \multicolumn{4}{|c|}{$\begin{array}{l}\text { Treatment center: Memorial Sloan-Kettering Cancer Center } \\
\text { Date of diagnosis: } 5 / 01 / 07 \\
\text { Age at diagnosis: } 37 / 12 \\
\text { Date of completion of therapy: } 03 / 01 / 12\end{array}$} \\
\hline \multicolumn{4}{|c|}{ Surgery } \\
\hline \multicolumn{2}{|l|}{ Date } & & \\
\hline $6 / 20 / 07$ & \multicolumn{3}{|c|}{$\begin{array}{l}\text { Thoracoabdominal exploration and gross total resection of neuroblastoma. } \\
\text { Right radical adrenalectomy. Liver biopsy. }\end{array}$} \\
\hline \multicolumn{4}{|l|}{ Radiation Therapy } \\
\hline Date Start & \begin{tabular}{|l|} 
Date Stop \\
\end{tabular} & Field & Dose (cGy) \\
\hline $09 / 01 / 07$ & $09 / 12 / 07$ & Abdomen & 2100 \\
\hline \multicolumn{4}{|l|}{ Chemotherapy } \\
\hline \multicolumn{2}{|l|}{ Drug Name } & \multirow{2}{*}{\multicolumn{2}{|c|}{ Dose (units or $\mathrm{mg} / \mathrm{m}^{2}$ ) }} \\
\hline \multicolumn{3}{|l|}{ Isotretinoin } & \\
\hline \multicolumn{4}{|l|}{ Topotecan } \\
\hline \multicolumn{4}{|l|}{ Irinotecan } \\
\hline \multicolumn{4}{|l|}{ Temozolomide } \\
\hline \multicolumn{2}{|l|}{ Cyclophosphamide } & \multicolumn{2}{|c|}{17.6 grams $/ \mathrm{m}^{2}$} \\
\hline \multicolumn{2}{|l|}{ Carboplatin } & \\
\hline \multicolumn{2}{|l|}{ Cisplatin } & \multicolumn{2}{|l|}{$400 \mathrm{mg} / \mathrm{m}^{2}$} \\
\hline \multicolumn{4}{|l|}{ Etoposide } \\
\hline \multicolumn{4}{|l|}{ Vincristine } \\
\hline \multicolumn{2}{|l|}{ Doxorubicin } & \multicolumn{2}{|l|}{$225 \mathrm{mg} / \mathrm{m}^{2}$} \\
\hline \multicolumn{4}{|l|}{ Immunotherapy } \\
\hline 3F8/GMCSF & & & \\
\hline Rituximab & & & \\
\hline Potential Late Effects & & Screening & tions $\mathbf{s}^{* *}$ \\
\hline Any treatment history & & Complete p & annually \\
\hline Neurocognitive dysfuncti & & Neuropsycl & tation \\
\hline Hearing problems & & Audiogram & indicated \\
\hline Thyroid problems & & TSH/Free 1 & palpate thyroid \\
\hline Cardiac dysfunction & & Echocardio & ery $1-3$ years \\
\hline GI dysfunction & & Liver Funct & ally \\
\hline Kidney/Bladder dysfunct 1 & & BUN/Creat & essure, urinalysis \\
\hline Gonadal dysfunction/infe & itility & $\begin{array}{l}\text { LH/FSH, T } \\
\text { sperm analy }\end{array}$ & $\begin{array}{l}\text { onitor pubertal development, } \\
\text { cated }\end{array}$ \\
\hline Decreased spinal growth & & Monitor we & nd sitting height \\
\hline Altered bone health & & Bone densi & $s$ indicated \\
\hline Secondary malignancies & & $\begin{array}{l}\text { CBC annua } \\
\text { dermatolog }\end{array}$ & $\begin{array}{l}\text { d palpate radiation areas, } \\
\text { ly, UA annually }\end{array}$ \\
\hline Dental problems & & Dental exar & every 6 months \\
\hline $\begin{array}{l}\text { **Screening recommen } \\
\text { Guidelines: } \underline{\text { http: }: / \text { www }}\end{array}$ & $\begin{array}{l}\text { dations ad } \\
\text { survivors }\end{array}$ & $\begin{array}{l}\text { he Children's } \\
\text { s.org. }\end{array}$ & up Long-Term Follow-Up \\
\hline
\end{tabular}

Figure 1. Sample treatment summary for a survivor of neuroblastoma. Abbreviations: cGy, centigray; GM-CSF, Granulocyte-Macrophage Colony Stimulating Factor; TSH, thyroid stimulating hormone; free T4, free thyroxine; EKG, electrocardiogram; BUN, blood urea nitrogen; LH, luteinizing hormone; $\mathrm{FSH}$, follicle stimulating hormone; $\mathrm{CBC}$, complete blood count; UA, urinalysis. 3F8 is a murine monoclonal IgG3 antibody specific for the tumor- associated antigen ganglioside GD2, which is used at Memorial Sloan Kettering Cancer Center.

\section{Conclusions}

Neuroblastoma survivors face lifelong medical and psychosocial risks related to their prior cancer therapies. The most prevalent complications in this cohort include conditions involving hearing, the endocrine system, and SMN, although survivors are at risk for disturbances in other systems as 
well, as outlined above. In order to promote early identification and treatment of these problems, lifelong surveillance and risk-based follow-up care should be provided for all survivors, particularly those treated with intensive multimodality therapy. The goal of survivorship care for this cohort is to reduce morbidity and mortality, educate and empower both survivors and their families, and enhance quality of life among all neuroblastoma survivors.

Author Contributions: Conceptualization, Writing-Original Draft Preparation, Writing-Review and Editing: D.N.F.; Conceptualization, Writing-Review and Editing: T.O.H.

Funding: This research was funded by the MSK Cancer Center Support Grant/Core Grant, grant number P30 CA008748.

Conflicts of Interest: The authors declare no conflict of interest.

\section{References}

1. American Cancer Society. Cancer Facts \& Figures 2018; American Cancer Society: Atlanta, GA, USA, 2018.

2. Matthay, K.K.; Maris, J.M.; Schleiermacher, G.; Nakagawara, A.; Mackall, C.L.; Diller, L.; Weiss, W.A. Neuroblastoma. Nat. Rev. Dis. Primers 2016, 2, 16078. [CrossRef] [PubMed]

3. Cheung, N.K.; Lazarus, H.; Miraldi, F.D.; Abramowsky, C.R.; Kallick, S.; Saarinen, U.M.; Spitzer, T.; Strandjord, S.E.; Coccia, P.F.; Berger, N.A. Ganglioside GD2 specific monoclonal antibody 3F8: A phase I study in patients with neuroblastoma and malignant melanoma. J. Clin. Oncol. 1987, 5, 1430-1440. [CrossRef] [PubMed]

4. Finklestein, J.Z.; Klemperer, M.R.; Evans, A.; Bernstein, I.; Leikin, S.; McCreadie, S.; Grosfeld, J.; Hittle, R.; Weiner, J.; Sather, H.; et al. Multiagent chemotherapy for children with metastatic neuroblastoma: A report from childrens cancer study group. Med. Pediatr. Oncol. 1979, 6, 179-188. [CrossRef] [PubMed]

5. Green, A.A.; Hayes, F.A.; Hustu, H.O. Sequential cyclophosphamide and doxorubicin for induction of complete remission in children with disseminated neuroblastoma. Cancer 1981, 48, 2310-2317. [CrossRef]

6. Hartmann, O.; Benhamou, E.; Beaujean, F.; Pico, J.L.; Kalifa, C.; Patte, C.; Flamant, F.; Lemerle, J. High-dose busulfan and cyclophosphamide with autologous bone marrow transplantation support in advanced malignancies in children: A phase II study. J. Clin. Oncol. 1986, 4, 1804-1810. [CrossRef] [PubMed]

7. Hartmann, O.; Kalifa, C.; Benhamou, E.; Patte, C.; Flamant, F.; Jullien, C.; Beaujean, F.; Lemerle, J. Treatment of advanced neuroblastoma with high-dose melphalan and autologous bone marrow transplantation. Cancer Chemother. Pharmacol. 1986, 16, 165-169. [CrossRef] [PubMed]

8. Matthay, K.K.; Huberty, J.P.; Hattner, R.S.; Ablin, A.R.; Engelstad, B.L.; Zoger, S.; Hasegawa, B.H.; Price, D. Efficacy and safety of [131i]metaiodobenzylguanidine therapy for patients with refractory neuroblastoma. J. Nucl. Biol. Med. 1991, 35, 244-247. [PubMed]

9. Matthay, K.K.; O'Leary, M.C.; Ramsay, N.K.; Villablanca, J.; Reynolds, C.P.; Atkinson, J.B.; Haase, G.M.; Stram, D.O.; Seeger, R.C. Role of myeloablative therapy in improved outcome for high risk neuroblastoma: Review of recent children's cancer group results. Eur. J. Cancer 1995, 31a, 572-575. [CrossRef]

10. Pinto, N.R.; Applebaum, M.A.; Volchenboum, S.L.; Matthay, K.K.; London, W.B.; Ambros, P.F.; Nakagawara, A.; Berthold, F.; Schleiermacher, G.; Park, J.R.; et al. Advances in risk classification and treatment strategies for neuroblastoma. J. Clin. Oncol. 2015, 33, 3008-3017. [CrossRef] [PubMed]

11. Stram, D.O.; Matthay, K.K.; O'Leary, M.; Reynolds, C.P.; Haase, G.M.; Atkinson, J.B.; Brodeur, G.M.; Seeger, R.C. Consolidation chemoradiotherapy and autologous bone marrow transplantation versus continued chemotherapy for metastatic neuroblastoma: A report of two concurrent children's cancer group studies. J. Clin. Oncol. 1996, 14, 2417-2426. [CrossRef] [PubMed]

12. Strother, D.R.; London, W.B.; Schmidt, M.L.; Brodeur, G.M.; Shimada, H.; Thorner, P.; Collins, M.H.; Tagge, E.; Adkins, S.; Reynolds, C.P.; et al. Outcome after surgery alone or with restricted use of chemotherapy for patients with low-risk neuroblastoma: Results of children's oncology group study p9641. J. Clin. Oncol. 2012, 30, 1842-1848. [CrossRef] [PubMed]

13. Matthay, K.K.; Reynolds, C.P.; Seeger, R.C.; Shimada, H.; Adkins, E.S.; Haas-Kogan, D.; Gerbing, R.B.; London, W.B.; Villablanca, J.G. Long-term results for children with high-risk neuroblastoma treated on a randomized trial of myeloablative therapy followed by 13-cis-retinoic acid: A children's oncology group study. J. Clin. Oncol. 2009, 27, 1007-1013. [CrossRef] [PubMed] 
14. Matthay, K.K.; Villablanca, J.G.; Seeger, R.C.; Stram, D.O.; Harris, R.E.; Ramsay, N.K.; Swift, P.; Shimada, H.; Black, C.T.; Brodeur, G.M.; et al. Treatment of high-risk neuroblastoma with intensive chemotherapy, radiotherapy, autologous bone marrow transplantation, and 13-cis-retinoic acid. N. Engl. J. Med. 1999, 341, 1165-1173. [CrossRef] [PubMed]

15. Park, J.R.; Villablanca, J.G.; London, W.B.; Gerbing, R.B.; Haas-Kogan, D.; Adkins, E.S.; Attiyeh, E.F.; Maris, J.M.; Seeger, R.C.; Reynolds, C.P.; et al. Outcome of high-risk stage 3 neuroblastoma with myeloablative therapy and 13-cis-retinoic acid: A report from the children's oncology group. Pediatr. Blood Cancer 2009, 52, 44-50. [CrossRef] [PubMed]

16. Kletzel, M.; Katzenstein, H.M.; Haut, P.R.; Yu, A.L.; Morgan, E.; Reynolds, M.; Geissler, G.; Marymount, M.H.; Liu, D.; Kalapurakal, J.A.; et al. Treatment of high-risk neuroblastoma with triple-tandem high-dose therapy and stem-cell rescue: Results of the chicago pilot II study. J. Clin. Oncol. 2002, 20, 2284-2292. [CrossRef] [PubMed]

17. George, R.E.; Li, S.; Medeiros-Nancarrow, C.; Neuberg, D.; Marcus, K.; Shamberger, R.C.; Pulsipher, M.; Grupp, S.A.; Diller, L. High-risk neuroblastoma treated with tandem autologous peripheral-blood stem cell-supported transplantation: Long-term survival update. J. Clin. Oncol. 2006, 24, 2891-2896. [CrossRef] [PubMed]

18. Armstrong, A.E.; Danner-Koptik, K.; Golden, S.; Schneiderman, J.; Kletzel, M.; Reichek, J.; Gosiengfiao, Y. Late effects in pediatric high-risk neuroblastoma survivors after intensive induction chemotherapy followed by myeloablative consolidation chemotherapy and triple autologous stem cell transplants. J. Pediatr. Hematol. Oncol. 2018, 40, 31-35. [CrossRef] [PubMed]

19. Barr, R.D.; Chalmers, D.; Pauw, S.D.; Furlong, W.; Weitzman, S.; Feeny, D. Health-related quality of life in survivors of wilms' tumor and advanced neuroblastoma: A cross-sectional study. J. Clin. Oncol. 2000, 18, 3280-3287. [CrossRef] [PubMed]

20. Cohen, L.E.; Gordon, J.H.; Popovsky, E.Y.; Gunawardene, S.; Duffey-Lind, E.; Lehmann, L.E.; Diller, L.R. Late effects in children treated with intensive multimodal therapy for high-risk neuroblastoma: High incidence of endocrine and growth problems. Bone Marrow Transplant. 2014, 49, 502-508. [CrossRef] [PubMed]

21. Laverdiere, C.; Cheung, N.K.; Kushner, B.H.; Kramer, K.; Modak, S.; LaQuaglia, M.P.; Wolden, S.; Ness, K.K.; Gurney, J.G.; Sklar, C.A. Long-term complications in survivors of advanced stage neuroblastoma. Pediatr. Blood Cancer 2005, 45, 324-332. [CrossRef] [PubMed]

22. Laverdiere, C.; Liu, Q.; Yasui, Y.; Nathan, P.C.; Gurney, J.G.; Stovall, M.; Diller, L.R.; Cheung, N.K.; Wolden, S.; Robison, L.L.; et al. Long-term outcomes in survivors of neuroblastoma: A report from the childhood cancer survivor study. JNCI 2009, 101, 1131-1140. [CrossRef] [PubMed]

23. Applebaum, M.A.; Henderson, T.O.; Lee, S.M.; Pinto, N.; Volchenboum, S.L.; Cohn, S.L. Second malignancies in patients with neuroblastoma: The effects of risk-based therapy. Pediatr. Blood Cancer 2015, 62, 128-133. [CrossRef] [PubMed]

24. Robison, L.L. The childhood cancer survivor study: A resource for research of long-term outcomes among adult survivors of childhood cancer. Minn. Med. 2005, 88, 45-49. [PubMed]

25. Robison, L.L.; Armstrong, G.T.; Boice, J.D.; Chow, E.J.; Davies, S.M.; Donaldson, S.S.; Green, D.M.; Hammond, S.; Meadows, A.T.; Mertens, A.C.; et al. The childhood cancer survivor study: A national cancer institute-supported resource for outcome and intervention research. J. Clin. Oncol. 2009, 27, 2308-2318. [CrossRef] [PubMed]

26. Oeffinger, K.C.; Mertens, A.C.; Sklar, C.A.; Kawashima, T.; Hudson, M.M.; Meadows, A.T.; Friedman, D.L.; Marina, N.; Hobbie, W.; Kadan-Lottick, N.S.; et al. Chronic health conditions in adult survivors of childhood cancer. N. Engl. J. Med. 2006, 355, 1572-1582. [CrossRef] [PubMed]

27. Armstrong, G.T.; Chen, Y.; Yasui, Y.; Leisenring, W.; Gibson, T.M.; Mertens, A.C.; Stovall, M.; Oeffinger, K.C.; Bhatia, S.; Krull, K.R.; et al. Reduction in late mortality among 5-year survivors of childhood cancer. N. Engl. J. Med. 2016, 374, 833-842. [CrossRef] [PubMed]

28. Hobbie, W.L.; Moshang, T.; Carlson, C.A.; Goldmuntz, E.; Sacks, N.; Goldfarb, S.B.; Grupp, S.A.; Ginsberg, J.P. Late effects in survivors of tandem peripheral blood stem cell transplant for high-risk neuroblastoma. Pediatr. Blood Cancer 2008, 51, 679-683. [CrossRef] [PubMed] 
29. Trahair, T.N.; Vowels, M.R.; Johnston, K.; Cohn, R.J.; Russell, S.J.; Neville, K.A.; Carroll, S.; Marshall, G.M. Long-term outcomes in children with high-risk neuroblastoma treated with autologous stem cell transplantation. Bone Marrow Transplant. 2007, 40, 741-746. [CrossRef] [PubMed]

30. Applebaum, M.A.; Vaksman, Z.; Lee, S.M.; Hungate, E.A.; Henderson, T.O.; London, W.B.; Pinto, N.; Volchenboum, S.L.; Park, J.R.; Naranjo, A.; et al. Neuroblastoma survivors are at increased risk for second malignancies: A report from the international neuroblastoma risk group project. Eur. J. Cancer 2017, 72, 177-185. [CrossRef] [PubMed]

31. Bergeron, C.; Dubourg, L.; Chastagner, P.; Mechinaud, F.; Plouvier, E.; Desfachelles, A.S.; Dusol, F.; Pautard, B.; Edan, C.; Plantaz, D.; et al. Long-term renal and hearing toxicity of carboplatin in infants treated for localized and unresectable neuroblastoma: Results of the SFOP NBL90 study. Pediatr. Blood Cancer 2005, 45, 32-36. [CrossRef] [PubMed]

32. Landier, W.; Knight, K.; Wong, F.L.; Lee, J.; Thomas, O.; Kim, H.; Kreissman, S.G.; Schmidt, M.L.; Chen, L.; London, W.B.; et al. Ototoxicity in children with high-risk neuroblastoma: Prevalence, risk factors, and concordance of grading scales-A report from the children's oncology group. J. Clin. Oncol. 2014, 32, 527-534. [CrossRef] [PubMed]

33. De Fine Licht, S.; Rugbjerg, K.; Gudmundsdottir, T.; Bonnesen, T.G.; Asdahl, P.H.; Holmqvist, A.S.; Madanat-Harjuoja, L.; Tryggvadottir, L.; Wesenberg, F.; Hasle, H.; et al. Long-term inpatient disease burden in the adult life after childhood cancer in scandinavia (ALiCCS) study: A cohort study of 21,297 childhood cancer survivors. PLoS Med. 2017, 14, e1002296. [CrossRef] [PubMed]

34. Brignardello, E.; Felicetti, F.; Castiglione, A.; Chiabotto, P.; Corrias, A.; Fagioli, F.; Ciccone, G.; Boccuzzi, G. Endocrine health conditions in adult survivors of childhood cancer: The need for specialized adult-focused follow-up clinics. Eur. J. Endocrinol. 2013, 168, 465-472. [CrossRef] [PubMed]

35. Mostoufi-Moab, S.; Seidel, K.; Leisenring, W.M.; Armstrong, G.T.; Oeffinger, K.C.; Stovall, M.; Meacham, L.R.; Green, D.M.; Weathers, R.; Ginsberg, J.P.; et al. Endocrine abnormalities in aging survivors of childhood cancer: A report from the childhood cancer survivor study. J. Clin. Oncol. 2016, 34, 3240-3247. [CrossRef] [PubMed]

36. Van Santen, H.M.; de Kraker, J.; Vulsma, T. Endocrine late effects from multi-modality treatment of neuroblastoma. Eur. J. Cancer 2005, 41, 1767-1774. [CrossRef] [PubMed]

37. Flandin, I.; Hartmann, O.; Michon, J.; Pinkerton, R.; Coze, C.; Stephan, J.L.; Fourquet, B.; Valteau-Couanet, D.; Bergeron, C.; Philip, T.; et al. Impact of TBI on late effects in children treated by megatherapy for stage iv neuroblastoma. A study of the French society of pediatric oncology. Int. J. Radiat. Oncol. Biol. Phys. 2006, 64, 1424-1431. [CrossRef] [PubMed]

38. Sklar, C.; Boulad, F.; Small, T.; Kernan, N. Endocrine complications of pediatric stem cell transplantation. Front. Biosci. J. Virtual Libr. 2001, 6, G17-G22. [CrossRef]

39. Clement, S.C.; van Eck-Smit, B.L.; van Trotsenburg, A.S.; Kremer, L.C.; Tytgat, G.A.; van Santen, H.M. Long-term follow-up of the thyroid gland after treatment with 131I-metaiodobenzylguanidine in children with neuroblastoma: Importance of continuous surveillance. Pediatr. Blood Cancer 2013, 60, 1833-1838. [CrossRef] [PubMed]

40. Clement, S.C.; van Rijn, R.R.; van Eck-Smit, B.L.; van Trotsenburg, A.S.; Caron, H.N.; Tytgat, G.A.; van Santen, H.M. Long-term efficacy of current thyroid prophylaxis and future perspectives on thyroid protection during 131I-metaiodobenzylguanidine treatment in children with neuroblastoma. Eur. J. Nucl. Med. Mol. Imaging 2015, 42, 706-715. [CrossRef] [PubMed]

41. Van Santen, H.M.; de Kraker, J.; van Eck, B.L.; de Vijlder, J.J.; Vulsma, T. High incidence of thyroid dysfunction despite prophylaxis with potassium iodide during (131)I-meta-iodobenzylguanidine treatment in children with neuroblastoma. Cancer 2002, 94, 2081-2089. [CrossRef] [PubMed]

42. Hovi, L.; Saarinen-Pihkala, U.M.; Vettenranta, K.; Lipsanen, M.; Tapanainen, P. Growth in children with poor-risk neuroblastoma after regimens with or without total body irradiation in preparation for autologous bone marrow transplantation. Bone Marrow Transplant. 1999, 24, 1131-1136. [CrossRef] [PubMed]

43. Giorgiani, G.; Bozzola, M.; Locatelli, F.; Picco, P.; Zecca, M.; Cisternino, M.; Dallorso, S.; Bonetti, F.; Dini, G.; Borrone, C.; et al. Role of busulfan and total body irradiation on growth of prepubertal children receiving bone marrow transplantation and results of treatment with recombinant human growth hormone. Blood 1995, 86, 825-831. [PubMed] 
44. Utriainen, P.; Vatanen, A.; Toiviainen-Salo, S.; Saarinen-Pihkala, U.; Makitie, O.; Jahnukainen, K. Skeletal outcome in long-term survivors of childhood high-risk neuroblastoma treated with high-dose therapy and autologous stem cell rescue. Bone Marrow Transplant. 2017, 52, 711-716. [CrossRef] [PubMed]

45. Sklar, C.A. Growth and neuroendocrine dysfunction following therapy for childhood cancer. Pediatr. Clin. N. Am. 1997, 44, 489-503. [CrossRef]

46. Clayton, P.E.; Shalet, S.M. The evolution of spinal growth after irradiation. Clin. Oncol. 1991, 3, $220-222$. [CrossRef]

47. Hobbie, W.L.; Mostoufi, S.M.; Carlson, C.A.; Gruccio, D.; Ginsberg, J.P. Prevalence of advanced bone age in a cohort of patients who received cis-retinoic acid for high-risk neuroblastoma. Pediatr. Blood Cancer 2011, 56, 474-476. [CrossRef] [PubMed]

48. Wilson, C.L.; Ness, K.K. Bone mineral density deficits and fractures in survivors of childhood cancer. Curr. Osteoporos. Rep. 2013, 11, 329-337. [CrossRef] [PubMed]

49. Green, D.M.; Sklar, C.A.; Boice, J.D., Jr.; Mulvihill, J.J.; Whitton, J.A.; Stovall, M.; Yasui, Y. Ovarian failure and reproductive outcomes after childhood cancer treatment: Results from the childhood cancer survivor study. J. Clin. Oncol. 2009, 27, 2374-2381. [CrossRef] [PubMed]

50. Sklar, C.A.; Mertens, A.C.; Mitby, P.; Whitton, J.; Stovall, M.; Kasper, C.; Mulder, J.; Green, D.; Nicholson, H.S.; Yasui, Y.; et al. Premature menopause in survivors of childhood cancer: A report from the childhood cancer survivor study. JNCI 2006, 98, 890-896. [CrossRef] [PubMed]

51. Levine, J.M.; Whitton, J.A.; Ginsberg, J.P.; Green, D.M.; Leisenring, W.M.; Stovall, M.; Robison, L.L.; Armstrong, G.T.; Sklar, C.A. Nonsurgical premature menopause and reproductive implications in survivors of childhood cancer: A report from the childhood cancer survivor study. Cancer 2018, 124, 1044-1052. [CrossRef] [PubMed]

52. Clement, S.C.; Kraal, K.C.; van Eck-Smit, B.L.; van den Bos, C.; Kremer, L.C.; Tytgat, G.A.; van Santen, H.M. Primary ovarian insufficiency in children after treatment with 131I-metaiodobenzylguanidine for neuroblastoma: Report of the first two cases. J. Clin. Endocrinol. Metab. 2014, 99, E112-E116. [CrossRef] [PubMed]

53. Armstrong, G.T.; Chow, E.J.; Sklar, C.A. Alterations in pubertal timing following therapy for childhood malignancies. Endocr. Dev. 2009, 15, 25-39. [PubMed]

54. Green, D.M.; Kawashima, T.; Stovall, M.; Leisenring, W.; Sklar, C.A.; Mertens, A.C.; Donaldson, S.S.; Byrne, J.; Robison, L.L. Fertility of male survivors of childhood cancer: A report from the childhood cancer survivor study. J. Clin. Oncol. 2010, 28, 332-339. [CrossRef] [PubMed]

55. Green, D.M.; Liu, W.; Kutteh, W.H.; Ke, R.W.; Shelton, K.C.; Sklar, C.A.; Chemaitilly, W.; Pui, C.H.; Klosky, J.L.; Spunt, S.L.; et al. Cumulative alkylating agent exposure and semen parameters in adult survivors of childhood cancer: A report from the st jude lifetime cohort study. Lancet Oncol. 2014, 15, 1215-1223. [CrossRef]

56. Wasilewski-Masker, K.; Seidel, K.D.; Leisenring, W.; Mertens, A.C.; Shnorhavorian, M.; Ritenour, C.W.; Stovall, M.; Green, D.M.; Sklar, C.A.; Armstrong, G.T.; et al. Male infertility in long-term survivors of pediatric cancer: A report from the childhood cancer survivor study. J. Cancer Surviv. 2014, 8, 437-447. [CrossRef] [PubMed]

57. Van Waas, M.; Neggers, S.J.; Pieters, R.; van den Heuvel-Eibrink, M.M. Components of the metabolic syndrome in 500 adult long-term survivors of childhood cancer. Ann. Oncol. 2010, 21, 1121-1126. [CrossRef] [PubMed]

58. Van Waas, M.; Neggers, S.J.; Raat, H.; van Rij, C.M.; Pieters, R.; van den Heuvel-Eibrink, M.M. Abdominal radiotherapy: A major determinant of metabolic syndrome in nephroblastoma and neuroblastoma survivors. PLoS ONE 2012, 7, e52237. [CrossRef] [PubMed]

59. Meacham, L.R.; Sklar, C.A.; Li, S.; Liu, Q.; Gimpel, N.; Yasui, Y.; Whitton, J.A.; Stovall, M.; Robison, L.L.; Oeffinger, K.C. Diabetes mellitus in long-term survivors of childhood cancer. Increased risk associated with radiation therapy: A report for the childhood cancer survivor study. Arch. Intern. Med. 2009, 169, 1381-1388. [CrossRef] [PubMed]

60. De Vathaire, F.; El-Fayech, C.; Ben Ayed, F.F.; Haddy, N.; Guibout, C.; Winter, D.; Thomas-Teinturier, C.; Veres, C.; Jackson, A.; Pacquement, H.; et al. Radiation dose to the pancreas and risk of diabetes mellitus in childhood cancer survivors: A retrospective cohort study. Lancet Oncol. 2012, 13, 1002-1010. [CrossRef] 
61. Chemaitilly, W.; Boulad, F.; Oeffinger, K.C.; Sklar, C.A. Disorders of glucose homeostasis in young adults treated with total body irradiation during childhood: A pilot study. Bone Marrow Transplant. 2009, 44, 339-343. [CrossRef] [PubMed]

62. Mayson, S.E.; Parker, V.E.; Schutta, M.H.; Semple, R.K.; Rickels, M.R. Severe insulin resistance and hypertriglyceridemia after childhood total body irradiation. Endocr. Pract. 2013, 19, 51-58. [CrossRef] [PubMed]

63. Wei, C.; Thyagiarajan, M.S.; Hunt, L.P.; Shield, J.P.; Stevens, M.C.; Crowne, E.C. Reduced insulin sensitivity in childhood survivors of haematopoietic stem cell transplantation is associated with lipodystropic and sarcopenic phenotypes. Pediatr. Blood Cancer 2015, 62, 1992-1999. [CrossRef] [PubMed]

64. Van Waas, M.; Wijnen, M.; Hartman, A.; de Vries, A.C.; Pieters, R.; Neggers, S.J.; van den Heuvel-Eibrink, M.M. Daily life physical activity in long-term survivors of nephroblastoma and neuroblastoma. J. Pediatr. Hematol. Oncol. 2013, 35, 361-365. [CrossRef] [PubMed]

65. Bertolini, P.; Lassalle, M.; Mercier, G.; Raquin, M.A.; Izzi, G.; Corradini, N.; Hartmann, O. Platinum compound-related ototoxicity in children: Long-term follow-up reveals continuous worsening of hearing loss. J. Pediatr. Hematol. Oncol. 2004, 26, 649-655. [CrossRef] [PubMed]

66. Grewal, S.; Merchant, T.; Reymond, R.; McInerney, M.; Hodge, C.; Shearer, P. Auditory late effects of childhood cancer therapy: A report from the children's oncology group. Pediatrics 2010, 125, e938-e950. [CrossRef] [PubMed]

67. Knight, K.R.; Kraemer, D.F.; Neuwelt, E.A. Ototoxicity in children receiving platinum chemotherapy: Underestimating a commonly occurring toxicity that may influence academic and social development. J. Clin. Oncol. 2005, 23, 8588-8596. [CrossRef] [PubMed]

68. Kushner, B.H.; Budnick, A.; Kramer, K.; Modak, S.; Cheung, N.K. Ototoxicity from high-dose use of platinum compounds in patients with neuroblastoma. Cancer 2006, 107, 417-422. [CrossRef] [PubMed]

69. Li, Y.; Womer, R.B.; Silber, J.H. Predicting cisplatin ototoxicity in children: The influence of age and the cumulative dose. Eur. J. Cancer 2004, 40, 2445-2451. [CrossRef] [PubMed]

70. Parsons, S.K.; Neault, M.W.; Lehmann, L.E.; Brennan, L.L.; Eickhoff, C.E.; Kretschmar, C.S.; Diller, L.R. Severe ototoxicity following carboplatin-containing conditioning regimen for autologous marrow transplantation for neuroblastoma. Bone Marrow Transplant. 1998, 22, 669-674. [CrossRef] [PubMed]

71. Simon, T.; Hero, B.; Dupuis, W.; Selle, B.; Berthold, F. The incidence of hearing impairment after successful treatment of neuroblastoma. Klin. Padiatr. 2002, 214, 149-152. [CrossRef] [PubMed]

72. Gurney, J.G.; Tersak, J.M.; Ness, K.K.; Landier, W.; Matthay, K.K.; Schmidt, M.L. Hearing loss, quality of life, and academic problems in long-term neuroblastoma survivors: A report from the children's oncology group. Pediatrics 2007, 120, e1229-e1236. [CrossRef] [PubMed]

73. Ryu, N.G.; Moon, I.J.; Chang, Y.S.; Kim, B.K.; Chung, W.H.; Cho, Y.S.; Hong, S.H. Cochlear implantation for profound hearing loss after multimodal treatment for neuroblastoma in children. Clin. Exp. Otorhinolaryngol. 2015, 8, 329-334. [CrossRef] [PubMed]

74. Huang, T.T.; Hudson, M.M.; Stokes, D.C.; Krasin, M.J.; Spunt, S.L.; Ness, K.K. Pulmonary outcomes in survivors of childhood cancer: A systematic review. Chest 2011, 140, 881-901. [CrossRef] [PubMed]

75. Neve, V.; Foot, A.B.; Michon, J.; Fourquet, A.; Zucker, J.M.; Boule, M. Longitudinal clinical and functional pulmonary follow-up after megatherapy, fractionated total body irradiation, and autologous bone marrow transplantation for metastatic neuroblastoma. Med. Pediatr. Oncol. 1999, 32, 170-176. [CrossRef]

76. Nenadov Beck, M.; Meresse, V.; Hartmann, O.; Gaultier, C. Long-term pulmonary sequelae after autologous bone marrow transplantation in children without total body irradiation. Bone Marrow Transplant. 1995, 16, 771-775. [PubMed]

77. Stone, A.; Novetsky Friedman, D.; Worgall, S.; Kushner, B.H.; Wolden, S.; Modak, S.; LaQuaglia, M.P.; Wu, X.; Cheung, N.K.; Sklar, C.A. Long-term pulmonary outcomes in pediatric survivors of high-risk neuroblastoma. J. Pediatr. Hematol. Oncol. 2017, 39, 547-554. [CrossRef] [PubMed]

78. Adams, M.; Traunecker, H.; Doull, I.; Cox, R. Bronchiectasis following treatment for high-risk neuroblastoma: A case series. Pediatr. Blood Cancer 2017, 64, e26509. [CrossRef] [PubMed]

79. Armstrong, G.T.; Oeffinger, K.C.; Chen, Y.; Kawashima, T.; Yasui, Y.; Leisenring, W.; Stovall, M.; Chow, E.J.; Sklar, C.A.; Mulrooney, D.A.; et al. Modifiable risk factors and major cardiac events among adult survivors of childhood cancer. J. Clin. Oncol. 2013, 31, 3673-3680. [CrossRef] [PubMed] 
80. Mulrooney, D.A.; Armstrong, G.T.; Huang, S.; Ness, K.K.; Ehrhardt, M.J.; Joshi, V.M.; Plana, J.C.; Soliman, E.Z.; Green, D.M.; Srivastava, D.; et al. Cardiac outcomes in adult survivors of childhood cancer exposed to cardiotoxic therapy: A cross-sectional study. Ann. Intern. Med. 2016, 164, 93-101. [CrossRef] [PubMed]

81. Long-Term Follow-Up Guidelines for Survivors of Childhood, Adolescent, and Young Adult Cancers. Available online: http:/ / survivorshipguidelines.org/ (accessed on 26 June 2018).

82. Mulrooney, D.A.; Yeazel, M.W.; Kawashima, T.; Mertens, A.C.; Mitby, P.; Stovall, M.; Donaldson, S.S.; Green, D.M.; Sklar, C.A.; Robison, L.L.; et al. Cardiac outcomes in a cohort of adult survivors of childhood and adolescent cancer: Retrospective analysis of the childhood cancer survivor study cohort. BMJ 2009, 339, b4606. [CrossRef] [PubMed]

83. Knijnenburg, S.L.; Mulder, R.L.; Schouten-Van Meeteren, A.Y.; Bokenkamp, A.; Blufpand, H.; van Dulmen-den Broeder, E.; Veening, M.A.; Kremer, L.C.; Jaspers, M.W. Early and late renal adverse effects after potentially nephrotoxic treatment for childhood cancer. Cochrane Database Syst. Rev. 2013, CD008944. [CrossRef] [PubMed]

84. Beckham, T.H.; Casey, D.L.; LaQuaglia, M.P.; Kushner, B.H.; Modak, S.; Wolden, S.L. Renal function outcomes of high-risk neuroblastoma patients undergoing radiation therapy. Int. J. Radiat. Oncol. Biol. Phys. 2017, 99, 486-493. [CrossRef] [PubMed]

85. Federico, S.M.; Allewelt, H.B.; Spunt, S.L.; Hudson, M.M.; Wu, J.; Billups, C.A.; Jenkins, J.; Santana, V.M.; Furman, W.L.; McGregor, L.M. Subsequent malignant neoplasms in pediatric patients initially diagnosed with neuroblastoma. J. Pediatr. Hematol. Oncol. 2015, 37, e6-e12. [CrossRef] [PubMed]

86. Danner-Koptik, K.E.; Majhail, N.S.; Brazauskas, R.; Wang, Z.; Buchbinder, D.; Cahn, J.Y.; Dilley, K.J.; Frangoul, H.A.; Gross, T.G.; Hale, G.A.; et al. Second malignancies after autologous hematopoietic cell transplantation in children. Bone Marrow Transplant. 2013, 48, 363-368. [CrossRef] [PubMed]

87. Martin, A.; Schneiderman, J.; Helenowski, I.B.; Morgan, E.; Dilley, K.; Danner-Koptik, K.; Hatahet, M.; Shimada, H.; Cohn, S.L.; Kletzel, M.; et al. Secondary malignant neoplasms after high-dose chemotherapy and autologous stem cell rescue for high-risk neuroblastoma. Pediatr. Blood Cancer 2014, 61, 1350-1356. [CrossRef] [PubMed]

88. Kushner, B.H.; Cheung, N.K.; Kramer, K.; Heller, G.; Jhanwar, S.C. Neuroblastoma and treatment-related myelodysplasia/leukemia: The memorial sloan-kettering experience and a literature review. J. Clin. Oncol. 1998, 16, 3880-3889. [CrossRef] [PubMed]

89. Kushner, B.H.; Kramer, K.; Modak, S.; Qin, L.X.; Yataghena, K.; Jhanwar, S.C.; Cheung, N.K. Reduced risk of secondary leukemia with fewer cycles of dose-intensive induction chemotherapy in patients with neuroblastoma. Pediatr. Blood Cancer 2009, 53, 17-22. [CrossRef] [PubMed]

90. Paulino, A.C.; Fowler, B.Z. Secondary neoplasms after radiotherapy for a childhood solid tumor. Pediatr. Hematol. Oncol. 2005, 22, 89-101. [CrossRef] [PubMed]

91. Turcotte, L.M.; Liu, Q.; Yasui, Y.; Arnold, M.A.; Hammond, S.; Howell, R.M.; Smith, S.A.; Weathers, R.E.; Henderson, T.O.; Gibson, T.M.; et al. Temporal trends in treatment and subsequent neoplasm risk among 5-year survivors of childhood cancer, 1970-2015. JAMA 2017, 317, 814-824. [CrossRef] [PubMed]

92. Rubino, C.; Adjadj, E.; Guerin, S.; Guibout, C.; Shamsaldin, A.; Dondon, M.G.; Valteau-Couanet, D.; Hartmann, O.; Hawkins, M.; de Vathaire, F. Long-term risk of second malignant neoplasms after neuroblastoma in childhood: Role of treatment. Int. J. Cancer 2003, 107, 791-796. [CrossRef] [PubMed]

93. Al-Mashaikhi, N.; Yang, J.; Terry, J.; Barr, R. Renal cell carcinoma with XP 11.2 translocation as a second tumor in a long-term survivor of advanced neuroblastoma. Pediatr. Hematol. Oncol. 2015, 32, $215-222$. [CrossRef] [PubMed]

94. Falzarano, S.M.; McKenney, J.K.; Montironi, R.; Eble, J.N.; Osunkoya, A.O.; Guo, J.; Zhou, S.; Xiao, H.; Dhanasekaran, S.M.; Shukla, S.; et al. Renal cell carcinoma occurring in patients with prior neuroblastoma: A heterogenous group of neoplasms. Am. J. Surg. Pathol. 2016, 40, 989-997. [CrossRef] [PubMed]

95. Schafernak, K.T.; Yang, X.J.; Hsueh, W.; Leestma, J.L.; Stagl, J.; Goldman, S. Pediatric renal cell carcinoma as second malignancy: Reports of two cases and a review of the literature. Can. J. Urol. 2007, 14, 3739-3744. [PubMed]

96. Wallace, B.; Organ, M.; Bagnell, S.; Rendon, R.; Merrimen, J. Renal cell carcinoma after neuroblastoma: A case study and review of the literature. Can. Urol. Assoc. J. 2015, 9, E316-E318. [CrossRef] [PubMed] 
97. Wilson, C.L.; Ness, K.K.; Neglia, J.P.; Hammond, S.; Shnorhavorian, M.; Leisenring, W.L.; Stovall, M.; Robison, L.L.; Armstrong, G.T. Renal carcinoma after childhood cancer: A report from the childhood cancer survivor study. JNCI 2013, 105, 504-508. [CrossRef] [PubMed]

98. Hudson, M.M.; Mulrooney, D.A.; Bowers, D.C.; Sklar, C.A.; Green, D.M.; Donaldson, S.S.; Oeffinger, K.C.; Neglia, J.P.; Meadows, A.T.; Robison, L.L. High-risk populations identified in childhood cancer survivor study investigations: Implications for risk-based surveillance. J. Clin. Oncol. 2009, 27, 2405-2414. [CrossRef] [PubMed]

99. Pappo, A.S.; Armstrong, G.T.; Liu, W.; Srivastava, D.K.; McDonald, A.; Leisenring, W.M.; Hammond, S.; Stovall, M.; Neglia, J.P.; Robison, L.L. Melanoma as a subsequent neoplasm in adult survivors of childhood cancer: A report from the childhood cancer survivor study. Pediatr. Blood Cancer 2013, 60, 461-466. [CrossRef] [PubMed]

100. Kushner, B.H.; Roberts, S.S.; Friedman, D.N.; Kuk, D.; Ostrovnaya, I.; Modak, S.; Kramer, K.; Basu, E.M.; Cheung, N.K. Osteochondroma in long-term survivors of high-risk neuroblastoma. Cancer 2015, 121, 2090-2096. [CrossRef] [PubMed]

101. Benz-Bohm, G.; Hero, B.; Gossmann, A.; Simon, T.; Korber, F.; Berthold, F. Focal nodular hyperplasia of the liver in longterm survivors of neuroblastoma: How much diagnostic imaging is necessary? Eur. J. Radiol. 2010, 74, e1-e5. [CrossRef] [PubMed]

102. Kulatunge, C.R.; Son, H. False-positive 123I-MIBG scintigraphy due to multiple focal nodular hyperplasia. Clin. Nucl. Med. 2013, 38, 976-978. [CrossRef] [PubMed]

103. Marabelle, A.; Campagne, D.; Dechelotte, P.; Chipponi, J.; Demeocq, F.; Kanold, J. Focal nodular hyperplasia of the liver in patients previously treated for pediatric neoplastic diseases. J. Pediatr. Hematol. Oncol. 2008, 30, 546-549. [CrossRef] [PubMed]

104. Sugito, K.; Uekusa, S.; Kawashima, H.; Furuya, T.; Ohashi, K.; Inoue, M.; Ikeda, T.; Koshinaga, T.; Tomita, R.; Mugishima, H.; et al. The clinical course in pediatric solid tumor patients with focal nodular hyperplasia of the liver. Int. J. Clin. Oncol. 2011, 16, 482-487. [CrossRef] [PubMed]

105. Zheng, D.J.; Krull, K.R.; Chen, Y.; Diller, L.; Yasui, Y.; Leisenring, W.; Brouwers, P.; Howell, R.; Lai, J.S.; Balsamo, L.; et al. Long-term psychological and educational outcomes for survivors of neuroblastoma: A report from the childhood cancer survivor study. Cancer 2018. Epub ahead of print. [CrossRef] [PubMed]

106. Schultz, K.A.; Ness, K.K.; Whitton, J.; Recklitis, C.; Zebrack, B.; Robison, L.L.; Zeltzer, L.; Mertens, A.C. Behavioral and social outcomes in adolescent survivors of childhood cancer: A report from the childhood cancer survivor study. J. Clin. Oncol. 2007, 25, 3649-3656. [CrossRef] [PubMed]

107. Nathan, P.C.; Ness, K.K.; Greenberg, M.L.; Hudson, M.; Wolden, S.; Davidoff, A.; Laverdiere, C.; Mertens, A.; Whitton, J.; Robison, L.L.; et al. Health-related quality of life in adult survivors of childhood wilms tumor or neuroblastoma: A report from the childhood cancer survivor study. Pediatr. Blood Cancer 2007, 49, 704-715. [CrossRef] [PubMed]

108. Kremer, L.C.; Mulder, R.L.; Oeffinger, K.C.; Bhatia, S.; Landier, W.; Levitt, G.; Constine, L.S.; Wallace, W.H.; Caron, H.N.; Armenian, S.H.; et al. A worldwide collaboration to harmonize guidelines for the long-term follow-up of childhood and young adult cancer survivors: A report from the international late effects of childhood cancer guideline harmonization group. Pediatr. Blood Cancer 2013, 60, 543-549. [CrossRef] [PubMed]

(C) 2018 by the authors. Licensee MDPI, Basel, Switzerland. This article is an open access article distributed under the terms and conditions of the Creative Commons Attribution (CC BY) license (http://creativecommons.org/licenses/by/4.0/). 